Embryo research

\section{British Commons vote for ban}

IN Britain last week, the House of Commons passed by a large majority (238 votes to 66) Mr Enoch Powell's emotively titled "Unborn Children (Protection) Bill" (see Nature 7 February, p.417), challenging both government and opposition alike. If the bill becomes law, all experiments on human embryos will be banned and it will be illegal to have in one's possession an embryo produced by in vitro fertilization (IVF) unless it is to be implanted into the uterus of a named woman with the aim of bringing the embryo to full term. For this, the permission of the Department of Health will be necessary.

Mr Kenneth Clarke, Minister for Health, represented the government's view, which is to introduce comprehensive legislation at some future date, based on the findings of the Warnock Committee (see Nature 312, 389; 1984). Despite pressure from back benchers in his own party, Mr Clarke refused to set a date for such a bill. The Warnock Committee took nearly two years to produce its report and the government has now invited comments on it from interested organizations. More than 120 such depositions have so far been received among which there is "little unanimity". Mr Clarke said that all these views must be considered before the drafting of any legislation, which will encompass much broader issues than the current bill, including surrogacy and the intricate problems of the legitimacy of children born through IVF or other techniques.

Mr Michael Meacher, the Labour opposition spokesman on health, somewhat unusually on the same side as the government, also spoke against the bill, arguing in favour of regulated research and pointing out the huge procedural task involved for the Department of Health in assessing IVF applications. He also warned of the wider implications of the bill for contraception and abortion.

Those in favour of the bill, however, had simpler points to make. Mr Powell's view is that embryos are people, and that killing people is wrong; he acknowledged last week that his bill would impede research, at least until other means are found, but said that this is the lesser evil. The spectre of the Nazi scientist was raised by several Members of Parliament (MPs), who felt that a blanket prevention of embryo research is safer than regulated licensed experiment. Mr Ian Paisley and Mr Norman St John Stevas both supported the bill on religious grounds, arguing that it is morally wrong to create life in order to discard it later.

Arguments against the bill plainly failed to impress most MPs. Ms Clare Short pointed out that the "test-tube" babies alive in Britain today would not have been born had the bill been law before the techniques had been developed. Several MPs, including Mrs Renee Short, Mr William
Hamilton and Mr David Couch (the parliamentary lay member of the Medical Research Council), described the potential benefits of IVF research in elucidating the causes of genetic defects and investigating male and female infertility, as well as the need to improve the success rate of IVF techniques. Despite these arguments, 170 Conservative MPs voted in favour of the bill, including the Leader of the House of Commons and the Chief Whip, on a free vote.

Next, the bill must pass through the commitee stage. The government's failure to prevent the bill so far and the bill's popularity with its own MPs will make it more difficult for it to delay or prevent the bill from passing through this notoriously thorny procedural step. The bill will also have to be passed by the House of Lords
Professor Jérôme Lejeune, the French geneticist who discovered the trisomy of chromosome X21 that causes Down's syndrome, seems to have had a great influence over British Members of Parliament (MPs) in their vote last week on human embryo research (see above).

A week before the debate, Lejeune addressed MPs and argued strongly that the research was unnecessary. So, repeatedly in the debate, MPs were quoting this "most eminent geneticist"' in justification of their votes. Lejeune, brought to Britain for the debate by the anti-abortion lobby, is described by some British scientists as a "very religious and very conservative" Roman Catholic.

In France, Lejeune is an active member of the pro-life lobby Laissez-les Vivre. Last week, he was quoted by MPs such as Mr Norman St John Stevas (who backed the bill), as saying that "[embryonic research] is not necessary" and by Sir Bernard Braine, who said that "It is clear from what he says that it is misleading nonsense to assert that experimentation up to 14 days can add anything at all to our knowledge of diseases such as muscular dystrophy... or cystic fibrosis", as by then the relevant tissues have not developed.

According to Sir Gerald Vaughan MP, Lejeune claimed at the pre-debate meeting that benefit from embryonic research was "very unlikely", and that "when one considers congenital conditions, the most profitable lines of research all lie in the chemical and vitamin field, many of them dealing with the mothers and not with the embryo"'.

This is Lejeune's line of research at the University of Paris, where he heads a group (at Paris $V$ ) investigating the role of "monocarbons", or $C_{1}$-radicals active in the developing brain, in causing Down's before it can become law. The government could remove much of the bill's support by announcing a definite timetable for its own legislation based on the findings of the Warnock report. Many of the Conservative MPs who voted for the bill last week would prefer government-sponsored legislation, but, in the absence of a definite date, would prefer to ban experimentation altogether than allow it to continue under present legislation.

Lady Warnock, speaking this week at King's College London, said that if the bill became law, the National Health Service IVF programme in Britain would end. She also explained that the minority opinion dissenting from her report's recommendation of a 14-day limit for embryo research and the reason why "people genuinely believe that science is up to no good" stemmed from the fear that the limit would not be adhered to rather than from opposition to experiments as such.

Maxine Clarke

\title{
French influence on Britain
}

syndrome.

Strangely enough, however, Lejeune's impact in France has been less than it appeared in Britain last week. The director of the French medical research council's research unit on reproductive physiology and psychology, Dr Emile Papiernik describes Lejeune as "a descriptive scientist, not in the field of experimentation". He added that in Britain "there seems to be a very conservative feeling at the present time"'.

Lejeune, speaking from Paris on Monday, said he was "very honoured"' but surprised to have had an influence over British MPs. He explained that his opposition to experimentation is on two levels: first, he believes that the fertilized egg is a human being, and that people should not be experimented upon; second, he "had not seen any argument" that convinced him that embryonic research would be beneficial.

Arguments in the Warnock report that the research could help cure Down's syndrome, haemophilia and muscular dystrophy were "just scientifically wrong", and anyway, he asks, why not do the research on embryonic material from animals like dogs and pigs?

Moreover, in Lejeune's view, in vitro fertilization (IVF) is not a treatment for infertility (whereas a repair of damaged fallopian tubes would be), but a cure for "childlessness": "There is a semantic distortion' in the debate, he says. Embryo research is not needed to treat infertility.

Lejeune has no objection to IVF, although he does object to the cryogenic preservation of embryos ("just a trick to have some material to hand").

He believes that many genetic diseases will be treatable with drugs without aborting a genetically disordered embryo.

Robert Walgate 